\title{
WHAT HAS BEEN ACCOMPLISHED IN CITY PLANNING DURING THE PAST YEAR
}

\author{
BY GEORGE B. FORD \\ New York City ${ }^{2}$
}

$\Omega \mathrm{H}$

HE past year was one of tremendous significance to the cause of city planning. Of the fifty-odd cities of over one hundred thousand population in the United States, twenty-two have made a distinct and notable contribution, in the past year, to the rapidly increasing volume of city planning history and achievement. Of the cities of from 25,000 to 100,000 population, which number about two hundred, twenty-nine may be counted on the roll of those that have made important and constructive advances in city planning, during the same period. A large number of cities and towns of lesser size have to their credit accomplishments which, in the mass, are not of the least importance. In Canada, despite the preoccupation of the people of the cities with the war, Thomas Adams, town planning adviser of the commission of conservation, reports a widespread interest and activity there, both in the formulation and passage of laws and in organization for constructive work. In Europe, and particularly in France and England, which countries I have had the good fortune to visit in the course of the past three months, city planning is not only alive,-it is making enormous strides as evidenced in the work which I saw under way in Paris, Marseilles, Lyons, Limoges, Rheims, and in London, not to mention numerous lesser places. In India, even, where one would be led to expect but little, British enthusiasm for city planning has roused the great and congested cities, such as Madras, Bombay and Calcutta to a realization of their city planning needs, and we are regularly in receipt of reports of progress being made there-progress which, indeed, would put many of our proud American cities to shame. The city planning movement has never enjoyed a more hopeful, indeed more constructive year than that just past.

It is peculiarly significant-and pregnant with a lesson of the utmost importance-that in the United States nearly 45 per cent of the cities of over 100,000 have taken great forward steps in town planning the past year-as against 15 per cent, less than one sixth, of the cities of lesser size (25,000 to 100,000 population) which show progress. Although it

${ }^{1}$ Address delivered at the annual meeting of the National Municipal League, at Springfield, Mass., November 23, 1916. See National Monicipal Review, vol. vi, p. 182. 
may be said that the larger cities contain a proportionately larger number of persons capable of appreciating and participating in a city planning movement, I believe the conclusion may be safely drawn that the large cities are finding the handicap of haphazard and uncontrolled city development intolerable, and are being forced to undertake scientific planning, at great expense in many cases, out of sheer self-preservation and to retrieve the losses, economic and social, which the piled-up neglect of past years has brought about. For the lesser cities, the lesson of the larger cities is assuming increasing significance. The cities of from 25,000 to 100,000 inhabitants have begun to realize - at least one sixth of them have done so in the past year-that the way to avoid the costly reconstruction, the losses to industry and trade-the social ills and hygienic hardships which follow in the wake of uncontrolled city growth-is to take a firm stand now, as against the day of expansion of trade, of extension of boundaries, of increase of population.

If we scan the record of accomplishment in city planning for the past year, one item in the hundreds that would bear report and analysis here if time permitted, stands out most strikingly. It is New York city's contribution-the districting or zoning ordinance passed by the board of estimate and apportionment in July last. Not since the inauguration of the movement for conscious city planning, back in 1893, has a page of city planning history been written which embodies so many vital and interesting features as the New York districting movement and the resulting ordinance. So much has been written about this and the way in which it was built up, that I must forego more than the briefest reference to this subject. The ordinance itself is a compromise in many respects-it is not drastic enough to serve as a model for other citiesbut it embodies all of the principles of the most advanced and comprehensive zoning program. The success attending the New York measure may be attributed to the thorough and unremitting campaign of education which was carried on, for the lack of which city planning has failed so often in America.

As a result of the success of the New York movement, we find that districting work is being organized, or is being actively promoted, or actually carried on, in the following municipalities:

Akron

Berkeley

Chicago

Baltimore

Cleveland

Des Moines

East Orange
Elgin

Little Rock

Los Angeles

Milwaukee

Minneapolis

Newark

Omaha
Ottawa

Philadelphia

Sacramento

St. Louis

Springfield, Mass.

Washington, D. C. 
This is certainly a remarkable showing considering the short space of time in which the movement has been gaining impetus-and one of the greatest significance.

However, during the past year, districting as a part of city planning has occupied public attention largely to the exclusion of the other aspects of the city planning problem, for much that is truly noteworthy has been done in other fields in the course of the past twelve months. Comprehensive city plans, varying enormously, however, in intrinsic merit and practical adaptability to actual conditions, are under way or have been prepared for the following cities:

$\begin{array}{lll}\text { Akron } & \text { Elgin } & \text { Omaha } \\ \text { Allentown } & \text { Johnstown } & \text { Ottawa, Ontario } \\ \text { Bayonne } & \text { Lawrence } & \text { Pasadena } \\ \text { Birmingham } & \text { Milwaukee } & \text { Pueblo } \\ \text { Brantford, Ontario } & \text { Minneapolis } & \text { Sacramento } \\ \text { East Boston, Mass. } & \text { Newark } & \text { St. Louis } \\ \text { East Orange } & \text { Oakland and Berkeley } & \text { South Philadelphia }\end{array}$

These plans cover all or a large number of the special phases of the city plan, including the street system, land subdivisions, transportation, waterfront improvement, parks, recreation, etc. The plans for Ottawa, for Oakland and Berkeley, and for Newark, are remarkable examples of the most advanced practice in investigation and planning, and that for Ot.tawa is presented in one of the most beautifully printed and illustrated reports yet published in America.

This brief review of the city planning accomplishment of the past year would, however, not be complete without a reference to the special studies on city planning problems made for various cities throughout America by city planners and landscape architects. Among the most notable are the following:

Boston, markets

Cambridge, study of building development, etc.

Camden, street replanning

Cleveland, street and bridge improvements

Denver, revision of the civic center plan

Fitchburg, study of main thoroughfares and street system

Holyoke, street planning studies

Madison, recreation survey and plan

Milwaukee, general survey and report

Peoria, streets and parks

Providence, plan for capitol site and thoroughfares

San Francisco, new plan for the exposition site

Springfield, control of billboard advertising, recreation

Vancouver, civic center plan 
Site planning, particularly for the provision of home sites on a large scale, has been undertaken by private enterprise in many cities, under the direction of town planners or landscape architects, during the past year. In this connection, also, special studies have been made for the housing of workingmen. In this class, the following are particularly noteworthy, as having been consummated in the past year:

Akron, Firestone park development

Bridgeport, housing studies for the chamber of commerce

Duluth, Morgan park, for the U. S. Steel Corporation

Midland, Pa., townsite for industrial plant

Ojibway, Canada, new town for the U. S. Steel Corporation

Passaic, Allwood garden village for the Brighton mills

Washington, D. C., Ellen Wilson memorial homes development

Waterbury, housing studies for local committee

Kenosha, housing development plan for local organization

These garden village or housing developments are not the least important of the town planning problems which have been under way or completed in the past year, for in this branch of city planning, we find an increasing opportunity to achieve permanent and notable results in the rectification of haphazard development on the perimeter of our rapidly growing cities.

Turning now to city planning legislation, we find an unprecedented activity throughout America among semi-public or official bodies, and in the legislatures of many states. In the past year, the following have been particularly active in the promotion, drafting or passage of laws or ordinances for city planning:

(a) California, permissive law for the appointment of city planning commissions.

Massachusetts, law providing for the appointment of boards of survey, with control over platting.

Pennsylvania, permissive law for appointment of a districting commission in cities of the first class.

Indiana, energetic steps for securing the passage of a city planning law.

(b) Ordinances in Akron, Bayonne, East Orange, Johnstown, Mansfield (Ohio), Mt. Vernon, Santa Monica (Calif.), Toledo, creating city planning commissions under state permissive laws. In Cincinnati, strenuous efforts by public-spirited citizens to secure appointive ordinance.

(c) Ordinances in Berkeley, New York and Sacramento, making districting control effective. Ordinances in Philadelphia, Minneapolis, creating districting commissions. Energetic steps being taken in St. Louis, St. Paul and Washington, D. C., to secure the advantages of districting control.

In Canada, the provinces Alberta, Saskatchewan, Manitoba, Ontario, Quebec, New Brunswick, and Nova Scotia, have secured provincial town planning acts based on the English town planning act of 1909, or are taking energetic steps to secure the passage of acts, and the cities of 
Vancouver, Edmonton, Calgary, Winnipeg, Toronto, Ottawa, St. John, are at work under such acts or are preparing to start on town planning pending the passage of acts.

The above remarkable record of a year's advance in city planning would not be complete without reference to recent developments in propagandist work for city planning during the past year. Perhaps the most interesting matter in this field is the conference of national organizations for co-operative endeavor in eity planning which met for the second time at the National Conference on City Planning, Cleveland, last June. At its meeting, a committee was appointed from among the delegates to study the possibilities of securing a national bureau for city planning and municipal investigation. Another development in this field in the past year, is the launching of the federation of Massachusetts planning boards, an accomplishment of which much could be said regarding its possibilities for promoting wider interest and constructive planning throughout the state. In Pennsylvania, Texas, California and other states, we find leagues of city planning commissions, meeting at regular periods to discuss the problems of city planning and to foster legislation and create public interest in the work.

All of us here present are keenly appreciative of the worth, even the vital necessity, of comprehensive planning for our towns and even for our counties and states. We cannot help but be inspired by the splendid showing which the nations of the world, and, in particular, our own country, have made during the last year. To those of us who have been at work in city planning during the past year, and who have come gradually to a realization of its great importance, it is our duty, I will say more, it is our privilege to spread the gospel far and wide throughout the land. A great campaign of education of the general public to the urgency of planning, either through the medium of a national bureau of city planning or through private organizations, is vitally necessary. It falls to our lot to see this through. 